\title{
Laser Light Treatment of Seeds for Improving the Biomass Photosynthesis, Chemical Composition and Biological Activities of Lemongrass Sprouts
}

\author{
Mohammad K. Okla ${ }^{1}$, Mohamed A. El-Tayeb ${ }^{1}$, Ahmed Ali Qahtan ${ }^{1}$, Mostafa A. Abdel-Maksoud ${ }^{2}$, \\ Yahya B. Elbadawi ${ }^{1}$, Mohamed Khamis Alaskary ${ }^{1}$, Mansour A. Balkhyour ${ }^{3}$, Abdelrahim H. A. Hassan ${ }^{4} \mathbb{D}$ \\ and Hamada AbdElgawad 5,6,*(D)
}

check for

updates

Citation: Okla, M.K.; El-Tayeb, M.A.; Qahtan, A.A.; Abdel-Maksoud, M.A.; Elbadawi, Y.B.; Alaskary, M.K.; Balkhyour, M.A.; Hassan, A.H.A.; AbdElgawad, H. Laser Light Treatment of Seeds for Improving the Biomass Photosynthesis, Chemical Composition and Biological Activities of Lemongrass Sprouts. Agronomy 2021, 11, 478. https://doi.org/ 10.3390/agronomy11030478

Received: 23 January 2021

Accepted: 24 February 2021

Published: 4 March 2021

Publisher's Note: MDPI stays neutral with regard to jurisdictional claims in published maps and institutional affiliations.

Copyright: (c) 2021 by the authors. Licensee MDPI, Basel, Switzerland. This article is an open access article distributed under the terms and conditions of the Creative Commons Attribution (CC BY) license (https:// creativecommons.org/licenses/by/ $4.0 /)$.
1 Botany and Microbiology Department, College of Science, King Saud University, P.O. Box 2455, Riyadh 11451, Saudi Arabia; malokla@ksu.edu.sa (M.K.O.); mali5@ksu.edu.sa (M.A.E.-T.); aqahtan@ksu.edu.sa (A.A.Q.); yalbadawi@ksu.edu.sa (Y.B.E.); 438106316@ksu.edu.sa (M.K.A.)

2 Zoology Department, College of Science, King Saud University, Riyadh 11461, Saudi Arabia; mabdelmaksoud@kau.edu.sa

3 Department of Environmental Science, Faculty of Meteorology, Environment and Arid Land Agriculture, King Abdulaziz University, P.O. Box 80200, Jeddah 21589, Saudi Arabia; mbalkhyour@kau.edu.sa

4 Department of Food Hygiene and Control, Faculty of Veterinary Medicine, Beni-Suef University, Beni-Suef 62511, Egypt; Abdelrahim@vet.bsu.edu.eg

5 Integrated Molecular Plant Physiology Research, Department of Biology, University of Antwerp, 2020 Antwerp, Belgium

6 Botany and Microbiology Department, Faculty of Science, Beni-Suef University, Beni-Suef 62521, Egypt

* Correspondence: hamada.abdelgawad@science.bsu.edu.eg

Abstract: Compared to seeds and mature plants, sprouts are well characterized based on their nutritive values and biological properties. Moreover, laser light application is known to be a promising approach to improving plant growth, photosynthesis, and nutraceutical values. However, no studies have investigated the phytochemicals and biological activity of lemongrass (Cymbopogon proximus (Hochst. ex A.Rich.) Chiov.) sprouts or the further improvement of their quality by applying laser light treatment. We carried out a preliminary experiment for the optimization of laser treatment conditions, finding that a helium neon (He-Ne) laser at $632 \mathrm{~nm}$ and $5 \mathrm{~mW}$ for $5 \mathrm{~min}$ provided the most favorable conditions. We then investigated fresh weight, photosynthetic reactions, and primary and secondary metabolites, including sugars, amino acids, organic acids, essential oils, and phenolic compounds. Moreover, we studied the effect of laser light-induced changes in chemical compositions on the antioxidant, anti-diabetic, and anti-cholesterol activities of Cymbopogon proximus sprouts grown from laser-treated seeds. Laser light treatment increased the photosynthesis and respiration and hence the fresh weight of Cymbopogon proximus sprouts. Overall, sprouting increased most bioactive primary and secondary metabolites as compared to seeds. Increased photosynthesis by laser light improved carbon allocation and raised non-structural carbohydrates, which in turn led to improved synthesis of amino acids, organic acids, and essential oils, as well as phenolic and flavonoid compounds. As a result, laser light significantly improved the antioxidant capacity in terms of increasing the levels of ferric reducing antioxidant power (FRAP) (from 9.5 to $21 \mu$ mole trolox/g fresh weight (FW)), oxygen radical absorbance (ORAC) (from 400 to $1100 \mu$ mole trolox/100 g FW), and DPPH (from $5 \%$ to $25 \%$ of inhibation) and enhanced the hypocholesterolemic and antidiabetic activity through increasing the percentage of cholesterol micellar solubility (CMS) inhibition (from $42 \%$ to $62 \%$ ) and glycemic index (from 33 to $17 \mu$ mole/g) over sprouts and seeds. In conclusion, the synergism of seed laser treatment and sprouting induced the health-promoting bioactive compounds in Cymbopogon proximus as compared to seeds, which can be applied at a large scale to improve the biochemical, physiological, and nutraceutical values of medicinal and crop sprouts.

Keywords: sprouts; laser irradiation; Cymbopogon proximus; photosynthesis; bioactive compounds; anti-cholesterol activity; anti-diabetic activity 


\section{Introduction}

Natural product research is now rapidly growing and attracting many research groups all over the world. Sprouts have been considered rich sources of health-promoting natural products such as amino acids, essential oils, polyphenols, minerals, and vitamins, which give them an advantage of being important food additives with various biological properties [1] As compared to seeds and mature plants and in addition to their high nutritive values, sprouts are also well characterized by their lower content of anti-nutritional factors [2]. Cymbopogon is a widely distributed plant genus and has been used in food additives [3]. It has pharmacological importance due to its highly enriched content of significant compounds like essential oils [4]. In this regard, this plant genus was traditionally associated with the treatment of several human diseases $[5,6]$, and many studies have revealed its anticancer, anti-inflammatory, antioxidant, antidiabetic and antimicrobial bioactivities [6-12]. Among the well-known lemongrass members are West Indian lemon grass (Cymbopogon citratus (DC.)) and Halfabar (Cymbopogon proximus (Hochst. ex A.Rich.) Chiov.), which have a characteristic lemon flavor. Cymbopogon proximus has many biological properties, including antioxidant, antimicrobial, and antiemetic activities [13-16]. Interestingly, it was also introduced as an antihypertensive agent after its observed hypotensive effect in experimentally induced hypertension in rats $[17,18]$. The essential oils from Cymbopogon proximus were proven to protect rats against isoproterenolinduced cardiac hypertrophy and fibrosis [19]. Thus, improving the phytochemical content of these plants, particularly their sprouts, is expected to enhance their health-promoting and functional food values. To enhance the nutritional and health-promoting effects of plants and their sprouts, several techniques that make use of environmental conditions have been applied to improve the production of nutritive phytochemicals [20-22]. In this regard, the application of laser light as the light source for plant production is a newly growing area of research and the possible positive effects of laser light on growing plants have been investigated. Laser light is classified into pulsed and continuous lasers. The continuous laser (e.g., He-Ne) and elevated $\mathrm{CO}_{2}$ have been employed in improving plant and sprout mass and bioactivity [20,21]. For example, He-Ne laser light improved fresh weight, increased minerals and antioxidant metabolites, and boosted the antioxidant capacity and the anti-inflammatory activities of buckwheat sprouts [21]. Laser light has induced a significant increase in the antioxidant capacity and biomass accumulation of sunflowers [23]. This growth and metabolism improvement by laser light is based on the ability of plant macromolecules to absorb light at a specific wavelength to trigger photosynthetic activity, resulting in an increased fresh weight [24]. Moreover, conversely, the use of specified lasers for indoor horticulture is a good solution to overcome the obstacles of using artificial lighting, where plants grown under laser illumination have completed their full growth cycle with phenotypes resembling those of plants grown under LEDs but with lower energy and cost [25]. As a consequence, in plant factories, the application of lasers for growing vegetables has become the first choice among other lighting options due to its energy-saving advantages [26]. Indeed, laser light application in plant production was found to enhance different growth stages, as well as physiological, biochemical, and yield attributes of plants, cereal crops, and vegetables [27]. In light of these recent findings, our current study was conducted, for the first time, to study the possible positive effects of sprouting and laser light application on phytochemicals and the bioactivity of $C$. proximus. We hypothesized that laser light could improve the sprouting impact on the bioactive phytochemicals, antioxidant capacity, hypocholesterolemic activity, biological activities, and health-promoting values of Cymbopogon proximus as compared to their seeds.

\section{Materials and Methods}

\subsection{Plant Material and Experimental Conditions}

Cymbopogon proximus seeds were collected from Field Crops Research Institute, Agricultural Research Centre, Giza, Egypt. Before laser re-illumination, seeds were soaked in distilled water for two hours, then they were categorized into two groups (with each group containing 100 seeds), i.e., a control group (non-irradiated) and a laser-irradiated 
group. The light source (a helium-neon (He-Ne) laser, equipment whitening, laser II, DMC Equipment Ltd., São Carlos, SP, Brasil) was used to treat seeds. Seeds were irradiated for $5 \mathrm{~min}$ under the following conditions $-632 \mathrm{~nm}$, a power of $5 \mathrm{~mW}$ and $500 \mathrm{~mJ}$ energy, beam diameter $1 \mathrm{~mm}$ and with a distance of $12 \mathrm{~cm}$ between the seeds and the laser source. These laser treatment conditions were optimized based on a preliminary experiment (Table 1), in which we tested the effectiveness of three laser types-helium neon $(632 \mathrm{~nm}, 5 \mathrm{~mW})$, helium cadmium $(442 \mathrm{~nm}, 16 \mathrm{~mW})$ and argon $(514 \mathrm{~nm}, 8 \mathrm{~mW})$-at different exposure times $(0,2,5$, and $10 \mathrm{~min})$ on the plant fresh weight and the overall antioxidant capacity in terms of ferric reducing antioxidant power (FRAP). The pretreated seeds were kept and rinsed in distilled water and spread on trays lined with vermiculite and watered every two days with Milli-Q water, and $150 \mathrm{~mL}$ of aquaponic water was poured evenly in each tray. The trays were maintained in a controlled growth chamber $\left(25^{\circ} \mathrm{C}, 16 \mathrm{~h}\right.$ light $/ 8 \mathrm{~h}$ dark cycle $)$ managed through cool white fluorescent tubes with photosynthetically active radiation (PAR) of $400 \mu \mathrm{mol} \mathrm{m} \mathrm{m}^{-2} \mathrm{~s}^{-1}$ and a relative humidity of $60 \%$ per day. Ten-day-old sprouts from each tray were taken and weighed as fresh mass and stored at $-80^{\circ} \mathrm{C}$ for further biochemical analyses. Experiments were repeated 3 times. Approximately 15 plants were pooled from each tray and treated as biological replicates (each biological replicate was pooled from the same tray) and were used for each measurement.

Table 1. Effect of laser treatment on responses of sprouts in terms of plant fresh weight and antioxidant capacity (ferric reducing antioxidant power, FRAP). Helium-neon (632 nm, $5 \mathrm{~mW}$ ), helium cadmium $(442 \mathrm{~nm}, 16 \mathrm{~mW})$, and argon $(514 \mathrm{~nm}, 8 \mathrm{~mW})$ were applied at different exposure times $(0,2$, 5 and $10 \mathrm{~min})$. Data are represented by means \pm standard errors. Different small letters $(\mathrm{a}, \mathrm{b} . .$. above bars indicate significant differences between means at $p<0.05$.

\begin{tabular}{cccc}
\hline Time (min) & He-Ne_Laser & He-Ca_Laser & Ar_Laser \\
\hline 0 & $1.4 \pm 0.12 \mathrm{a}$ & FW (g/sprout $)$ & \\
\hline 2 & $1.8 \pm 0.06 \mathrm{~b}$ & $1.4 \pm 0.11 \mathrm{a}$ & $1.4 \pm 0.12 \mathrm{a}$ \\
\hline 5 & $2.1 \pm 0.05 \mathrm{~b}$ & $1.5 \pm 0.1 \mathrm{a}$ & $1.7 \pm 0.34$ \\
\hline 10 & $2.1 \pm 0.06 \mathrm{~b}$ & $1.8 \pm 0.13 \mathrm{~b}$ & $1.8 \pm 0.11 \mathrm{a}$ \\
\hline & & FRAP $(\mu \mathrm{b}$ ) trolox $/ \mathrm{gFW})$ & \\
\hline 0 & $13.1 \pm 0.5 \mathrm{a}$ & $13.1 \pm 0.5 \mathrm{a}$ & $13.1 \pm 0.5 \mathrm{a}$ \\
\hline 5 & $17.5 \pm 0.17 \mathrm{~b}$ & $14.1 \pm 0.19 \mathrm{a}$ & $13.9 \pm 0.74 \mathrm{a}$ \\
\hline 10 & $20.9 \pm 1.1 \mathrm{~b}$ & $18.3 \pm 0.25 \mathrm{~b}$ & $15.7 \pm 0.87 \mathrm{a}$ \\
\hline & $19.8 \pm 2.74 \mathrm{~b}$ & $17.3 \pm 0.9 \mathrm{ab}$ & $17.8 \pm 0.4 \mathrm{~b}$ \\
\hline
\end{tabular}

\subsection{Photosynthesis Analysis}

Photosynthesis and dark respiration of treated lemongrass sprouts $\left(\mu \mathrm{mol} \mathrm{CO}_{2} \mathrm{~m}^{-2} \mathrm{~s}^{-1}\right)$ were measured by utilizing an EGM-4 infrared gas analyzer (PP Systems, Hitchin, UK). Wholesprout photosynthesis and dark respiration were determined from $180 \mathrm{~s}$ measurements of net carbon dioxide exchange (NE).

\subsection{Metabolite Analyses}

2.3.1. Primary Metabolism

Sugar Analysis

The estimation of sugar levels in plant samples was carried out as previously described by Abdelgawad et al. [28], using high-performance liquid chromatography (HPLC), with a UPLC TQD device (Milford, Worcester County, MA, USA). Sugars were extracted from Cymbopogon proximus seeds or sprouts in $2 \mathrm{~mL}$ of the acetonitrile/water (1:1, v/v). After boiling at $55-60{ }^{\circ} \mathrm{C}$ for $15 \mathrm{~min}$, then filtered through a Whatman No. 541 filter paper. Column temperature and injection volume were set at $30^{\circ} \mathrm{C}$ and $20 \mu \mathrm{L}$, respectively. The 
mobile phase was acetonitrile and HPLC-grade water, 75:25 $(v / v)$ at $1 \mathrm{~mL} \cdot \mathrm{min}^{-1}$. Identified sugars were quantified using peak areas and a comparison with a calibration curve obtained with the corresponding standards.

Amino Acid Analysis

Extraction: Amino acids were extracted by homogenizing $100 \mathrm{mg}$ of lemongrass sprouts or seeds in $1 \mathrm{~mL}$ of aqueous ethanol $(80 \%, v / v)$ using norvaline as an internal standard to increase the accuracy of quantitation, as well as to correct for different mass spectrometry responses.

Deamination: Amino acid analysis was undertaken using the method described by Zinta et al. [29]. The supernatant was centrifuged for $10 \mathrm{~min}$ at $8000 \mathrm{~g}$ using Millipore microfilters $(0.2 \mu \mathrm{m})$, the aqueous phase. The levels of amino acids were estimated using a Waters Acquity UPLC TQD device (Milford, Worcester County, MA, USA) coupled to a BEH amide column.

Organic Acid Analysis

Extraction: Organic acids were extracted in $0.1 \%$ phosphoric acid, performed using $500 \mathrm{mg}$ of sprout or seed powder, followed by the centrifugation of the mixture at $14,000 \mathrm{~g}$ for $30 \mathrm{~min}$ at $4{ }^{\circ} \mathrm{C}$.

Deamination: Clear supernatants were filtered through Millipore microfilters $(0.2 \mu \mathrm{m})$ and used for organic acid analyses using HPLC (Shimadzu HPLC system, SCL-10 AVP, Tokyo, Japan, reversed-phase at $4{ }^{\circ} \mathrm{C}$ ) coupled with a SUPELCOGELC-610H column and UV detector (LaChrom L-7455 diode series, Tokyo, Japan). The mobile phase used was phosphoric acid $(0.1 \%, v / v)$, which was run at a flow rate of $0.45 \mathrm{~mL} \mathrm{~min}^{-1}$.

\section{Essential Oil Analysis}

Extraction: Seeds or sprout samples were extracted with petroleum ether for $48 \mathrm{~h}$ at room temperature. The extract was evaporated to dryness using rotary evaporation at reduced pressure. The essential oil was passed over dark anhydrous sodium sulfate to remove moisture.

Deamination: The essential oils were analyzed through GC/MS, following the method described by Hassanpour et al. [30]. Seeds or sprouts were air-dried, then $10 \mathrm{~g}$ of the dried sample was used for the extraction of essential oils. The dried parts were subjected to steam distillation for $3 \mathrm{~h}$ using a Clevenger-type instrument and the essential oil content was then calculated as $\mathrm{mg} / \mathrm{g}$ fresh weight $(\mathrm{FW})$.

\subsubsection{Secondary Metabolites}

Determination of Phenolic Profile

Phenolic compounds were quantified through UHPLC-MS/MS analysis [31]. A known weight of the dried powdered sprouts or seeds was extracted $(80 \%, v / v)$ using ethanol at $70^{\circ} \mathrm{C}$ for $30 \mathrm{~min}$. After centrifugation (12,000 rpm for $\left.30 \mathrm{~min}\right)$, it was concentrated using a rotary evaporator (IKA-WERKE-RV06ML; Staufen, Germany). The obtained residue was dissolved in HPLC-grade methanol and analyzed by means of an Acquity UPLC System (Waters, Milford, CT, USA), equipped with an Acquity BEH C18 column $(100 \mathrm{~mm} \times 2.1 \mathrm{~mm}$, with a $1.7-\mu \mathrm{m}$ particle size). The mobile phase (A: ultrapure water containing $0.1 \%$ formic acid and eluent B: acetonitrile) was applied at a flow rate of $0.2 \mathrm{~mL} / \mathrm{min}$. The linear gradient of the mobile phase was started at $3 \% \mathrm{~B}$, increased to $100 \%$ B in $10 \mathrm{~min}$. The internal standard was 3,5-dichloro-4-hydroxybenzoic acid.

\subsection{Biological Activity}

Extraction: Samples were separately ground and extracted with ethanol at room temperature for $12 \mathrm{~h}$. The extract was centrifuged at $8000 \mathrm{~g}$ for $25 \mathrm{~min}$ and the supernatant was filtered using Whatmann No. 1 filter paper. After concentrating the extract using a rotary evaporator, the samples were stored at $-20{ }^{\circ} \mathrm{C}$ until use. 


\subsection{Antioxidant Capacity}

We used the DPPH (2,2-diphenyl-1-picryl-hydrazyl-hydrate), oxygen radical absorbance (ORAC) and ferric reducing antioxidant power (FRAP) assays to measure total antioxidant power in Cymbopogon proximus seeds, as described before [32]. Briefly, $0.25 \mathrm{~g}$ of the seed powder was extracted in ethanol $(80 \%)$ and centrifuged at $14,000 \mathrm{rpm}$ for $30 \mathrm{~min}$. The antioxidant capacity was measured by mixing $0.1 \mathrm{~mL}$ of the diluted seed extracts with $0.25 \mathrm{~mL}$ of the DPPH solution, ORAC (in the presence of $\mathrm{Cu}^{2+}$ and $\left.\mathrm{H}_{2} \mathrm{O}_{2}\right)$ or FRAP reagent, mixing TPTZ $(10 \mathrm{mM})$ and $\mathrm{FeCl}_{3}(20 \mathrm{mM})$ in acetate buffer $(0.25 \mathrm{M}$, $\mathrm{pH}$ 3.6). After incubation at room temperature, the absorbance was measured at $517 \mathrm{~nm}$ and $600 \mathrm{~nm}$ using the spectrometric method, respectively. The copper-initiated prooxidant activity was calculated using (Area Blank - Area Sample)/Area Blank $\times 100$ and expressed as prooxidant units; one unit equaled the prooxidant activity that reduced the area under the fluorescein decay curve by $1 \%$ in the ORAC assay.

\subsection{Hypocholesterolemic Activity}

\subsubsection{Inhibition of Micellar Solubility of Cholesterol}

The effect of Cymbopogon proximus sprout and seed extracts on the micellar solubility of cholesterol was measured as described in Hozzien et al. [33]. Micellar solution (2 mM cholesterol, $10 \mathrm{mM}$ sodium taurocholate, $132 \mathrm{mM} \mathrm{NaCl}, 5 \mathrm{mM}$ oleic acid, $15 \mathrm{mM}$ sodium phosphate ( $\mathrm{pH} 7.4)$ at the rate of $10 \mathrm{mg} / \mathrm{mL}$ ) was mixed with the extract. The mixture was vortexed, then sonicated for $2 \mathrm{~min}$ and incubated at $37^{\circ} \mathrm{C}$ for $24 \mathrm{~h}$. The micellar solution was ultra-centrifuged at $40,000 \mathrm{rpm}$ for $50 \mathrm{~min}$ at $22^{\circ} \mathrm{C}$. The supernatant was used for spectrophotometric determination of cholesterol content at $500 \mathrm{~nm}$ by means of an enzymatic method using a cholesterol analysis kit (C7510-Pointe Scientific, Inc., Canton, MI, USA). Inhibition activity of cholesterol micellar solubility was calculated.

\subsubsection{Pancreatic $\alpha$-Amylase Inhibition Assay}

To measure the inhibition of the pancreatic $\alpha$-amylase inhibition, the extract was mixed with a reaction solution (starch $(1 \mathrm{~g} / \mathrm{L})$ and phosphate buffer $(\mathrm{pH}$ 6.9). The reaction was started by adding $3 \mathrm{U} / \mathrm{mL}$ of amylase enzyme. After $10 \mathrm{~min}$ of incubation, $500 \mu \mathrm{L}$ dinitro salicylic (DNS) reagent was added to stop the reaction. The reaction mixture was heated for $10 \mathrm{~min}$ at $100{ }^{\circ} \mathrm{C}$. In the end, $500 \mu \mathrm{L}$ of $40 \%$ potassium sodium tartrate solution was added to the mixtures. The absorbance was recorded at $540 \mathrm{~nm}$.

\subsubsection{Pancreatic Lipase Inhibition Assay}

The inhibitory activity of Cymbopogon proximus sprout and seed extracts against pancreatic lipase was measured using 4-MUO, as described in Hozzien et al. [33]. Sprout extracts were mixed with $0.5 \mathrm{~mL}$ of the freshly prepared lipase $(1 \mathrm{mg} / \mathrm{mL}$; lipase from porcine pancreas, Sigma-Aldrich). After stirring, the reaction mixtures were centrifuged at $4000 \mathrm{rpm}$ for $10 \mathrm{~min}$, and then $2 \mathrm{~mL}$ of the $4-\mathrm{MUO}(0.1 \mathrm{mM})$ solutions was added. The reaction mixture was incubated at $37^{\circ} \mathrm{C}$ and $0.2 \mathrm{~mL}$ aliquots were taken at different time points. The 4-MUO hydrolysis by lipase was measured fluorometrically (excitation wavelength of $350 \mathrm{~nm}$ and an emission wavelength of $450 \mathrm{~nm}$ ). We calculated IC50 values $(\mathrm{mg} / \mathrm{mL})$ to estimate the concentration of the sprout or seed extract that inhibited $50 \%$ of the pancreatic lipase activity.

\subsection{Anti-Diabetic Activity}

\subsubsection{Determination of In Vitro Glycemic Index}

The GI was determined by means of in vitro starch hydrolysis [34]. Seeds and sprouts were ground and incubated with pepsin $(100 \mathrm{mg} / \mathrm{mL})$ in a reaction buffer of $\mathrm{HCl}-\mathrm{KCl}$ buffer ( $\mathrm{pH}$ 1.5). After incubation for one hour at $40{ }^{\circ} \mathrm{C}$ under shaking conditions, the mixture was diluted in phosphate buffer ( $\mathrm{pH}$ 6.9) and then $\alpha$-amylase was added and incubated at $37^{\circ} \mathrm{C}$. Approximately 1-mL aliquots were taken every $30 \mathrm{~min}$ and boiled for $20 \mathrm{~min}$ to inactivate the amylase enzyme. Residual starch was converted to glucose by 
adding $0.4 \mathrm{M}$ pf sodium acetate buffer ( $\mathrm{pH} 4.75$ ) and $60 \mu \mathrm{L}$ amylo glucosidase, and the reaction mixture was incubated at $60{ }^{\circ} \mathrm{C}$ for $50 \mathrm{~min}$. Approximately $0.6-\mathrm{mL}$ aliquots were taken and incubated with $1.2 \mathrm{~mL}$ glucose oxidase/peroxidase at $37^{\circ} \mathrm{C}$ for $35 \mathrm{~min}$. The absorbance of the mixture was measured at $500 \mathrm{~nm}$. Starch digestion rate was expressed as the percentage of hydrolyzed starch at different times $(0,30,60,90,120$, and $180 \mathrm{~min})$. The hydrolysis and the area under the hydrolysis curve (AUC, 0-180 min) were calculated. Then, the hydrolysis index was calculated as the relation between the AUC for a sample and the AUC for a standard multiplied by 100.

\subsection{2. $\alpha$-Glucosidase Inhibition Assay}

The inhibition of $\alpha$-Glucosidase inhibition was determined [34]. The seed and sprout hydroethanolic extract was mixed with $\alpha$-glucosidase $(2 \mathrm{U} / \mathrm{mL})$ and incubated at $37{ }^{\circ} \mathrm{C}$ for $5 \mathrm{~min}$. Then, $1 \mathrm{mM}$ para-nitrophenyl glucopyranoside dissolved in $50 \mathrm{mM}$ phosphate buffer ( $\mathrm{pH}$ 6.8) was added to the reaction buffer and incubated for $20 \mathrm{~min}$ at $37^{\circ} \mathrm{C}$. The reaction was stopped by adding sodium carbonate $(1 \mathrm{M}) . \alpha$-Glucosidase activity was determined at $405 \mathrm{~nm}$ to quantify the amount of para-nitrophenolate released by para-nitrophenyl glucopyranoside and the $\alpha$-glucosidase inhibitory activity was calculated.

\subsection{3. $\alpha$-Amylase Inhibition Assay}

$\alpha$-Amylase inhibition was determined with the method described in [34]. Starch (2 mg) was mixed with $0.5 \mathrm{M}$ Tris- $\mathrm{HCl}$ buffer $\left(\mathrm{pH}\right.$ 6.9) and $0.01 \mathrm{M} \mathrm{CaCl}_{2}$. After boiling for $5 \mathrm{~min}$, samples were cooled at room temperature and incubated for $5 \mathrm{~min}$ at $37^{\circ} \mathrm{C}$. Then, we added $\alpha$-amylase $(\mathrm{U} / \mathrm{mL})$ and incubated it at $37^{\circ} \mathrm{C}$ for $10 \mathrm{~min}$. Subsequently, $500 \mu \mathrm{L}$ $0.1 \%$ 3,5-dinitro salicylic acid was added and incubated for $10 \mathrm{~min}$ at $100{ }^{\circ} \mathrm{C}$. After cooling, the absorbance was determined at $540 \mathrm{~nm}$. The $\alpha$-amylase inhibition was calculated.

\subsection{Statistical Analyses}

Statistical analyses were performed using the SPSS statistical package (SPSS Inc., Chicago, IL, USA). One-way analysis of variance (ANOVA) was applied to all data. Tukey's Test $(p \leq 0.05)$ was carried out as the post-hoc test for mean separations. Each experiment was replicated at least three times $(n=3-5)$. Hierarchical clustering (Pearson correlation) was generated using the Multi-Experimental Viewer (TM4 software package).

\section{Results and Discussion}

\subsection{Increased Photosynthesis and Respiration by Laser Light Improved Cymbopogon proximus Growth}

Laser light has been proven to enhance the fresh weight and nutritive values of plants [34] and sprouts [21]. When applied at a certain dose, laser light can successfully increase the internal energy of the seeds by converting light energy into chemical energy [24], which subsequently could be utilized to activate the physiological processes of plants, such as germination, photosynthesis, and respiration [27]. In this context, laser light could enhance chlorophyll content $[23,24]$. On the molecular level, transcriptome analysis has also revealed an upregulation in the genes responsible for photosynthesis in He-Ne laser-pretreated wheat seedlings [35]. In the current study, the laser-treated group of Cymbopogon proximus showed a perceived increase in the fresh weight $(43 \%)$ and the dry weight (64\%) in comparison with the control group, respectively (Table 2). This is in agreement with previous studies that have confirmed that laser light can exert an enhancing effect on growth and biomass accumulation in plants [23,24]. It was reported that laser pre-sowing seed treatments have enhanced the chlorophyll content and metabolically important enzymes of soybeans [27]. Consequently, the observed induction in plant growth after laser light treatment in the current study could be partially attributed to the increased chlorophyll content and consequently to the increased net photosynthetic activity after laser light application. Additionally, respiration improvement was observed, as indicated by the respiratory rate, which increased by about $20 \%$ in the laser-treated group in comparison to the control group (Table 2). This increase in the respiratory rate may be attributed to the 
enhancing effect of the laser on the metabolically important enzymes that play a central role in respiration [27].

Table 2. Effect of He-Ne laser light treatment on fresh weight, dry weight, photosynthesis, and respiration levels of Cymbopogon proximus sprouts. DW: dry weight; FW: fresh weight. Data are represented by means \pm standard errors. Different small letters $(a, b, \ldots)$ above bars indicate significant differences between means at $p<0.05$.

\begin{tabular}{ccc}
\hline & Control & Laser \\
\hline $\mathrm{FW}(\mathrm{g} /$ sprout $)$ & $1.45 \pm 0.2 \mathrm{a}$ & $2.08 \pm 0.26 \mathrm{~b}$ \\
\hline $\mathrm{DW}(\mathrm{g} /$ sprout $)$ & $0.15 \pm 0.05 \mathrm{a}$ & $0.25 \pm 0.03 \mathrm{~b}$ \\
\hline Photosynthesis $\left(\mu \mathrm{mol} \mathrm{CO} \mathrm{m}^{-2} \mathrm{~s}^{-1}\right)$ & $2.9 \pm 0.35 \mathrm{a}$ & $4.08 \pm 0.15 \mathrm{~b}$ \\
\hline Respiration $\left(\mu \mathrm{mol} \mathrm{CO} \mathrm{m}^{-2} \mathrm{~s}^{-1}\right)$ & $0.018 \pm 0.003 \mathrm{a}$ & $0.025 \pm 0.005 \mathrm{~b}$ \\
\hline
\end{tabular}

3.2. Improved Photosynthetic Reactions in Laser Light-Treated Cymbopogon proximus Sprouts Induced the Assumption of Bioactive Primary Metabolites

The tissue metabolites were improved after laser treatment, as indicated by the increased tissue levels of sugar, amino acid, and organic acids in Cymbopogon proximus sprouts from laser-treated seeds when compared with control sprouts, which also showed significantly higher results than control seeds. There was an increase in the levels of soluble sugars (90\%) and total sugars (48\%) in the laser-treated sprouts compared to the control sprouts. In addition, control sprouts revealed significantly $(p<0.05)$ higher values of sucrose, fructose, and total carbohydrates as compared to seeds (Table 3). It was reported that sugars are directly involved in plant development and growth [36,37], so the increased photosynthetic rate observed in the current study may point to increased sugar production. As a result, high sugar availability could induce the biosynthesis of other classes of primary and secondary metabolites, in which they are degraded by dark respiration to provide the needed C-skeleton and energy [38]. Similarly, most of the measured organic acids and amino acids were improved by laser treatment in sprouts grown from treated seeds compared to control sprouting. In addition, control sprouting presented higher levels of these acids than seeds (Table 3). The levels of many amino acids were increased significantly $(p<0.05)$ in laser-treated sprouts. The levels of lysine $(21 \%)$, isoleucine $(40 \%)$, glycine $(42 \%)$, phenylalanine $(50 \%)$, cystine $(88 \%)$, glutamine $(14 \%)$, and glutamic acid $(26 \%)$ were significantly increased in laser light-treated sprouts in comparison to the control sprouts, which displayed significantly higher contents than seeds as well (Table 3). The incapability of human bodies to synthesize certain amino acids is generating interest in increasing the concentrations of these essential amino acids in plants [39], so the observed increase in the amino acid levels after laser application in the current study could be considered a crucial advantage of applying this technique. In this regard, the accumulation of essential amino acids is an important factor that affects the plant's nutritional value, besides being involved in protein synthesis [39]. Moreover, amino acids are globally considered natural plant growth stimulators [40] and are currently used for improving plant productivity [41]. In the current study, the levels of malic, succinic, and citric acids were significantly $(p<0.05)$ increased in laser-treated sprouts compared to control sprouts, and these acids were significantly higher in control sprouts than in seeds (Table 3). The high sugars and organic acids reported in the treated Cymbopogon proximus sprouts could support their nutritional value because they are directly related to taste and flavor [42]. It has been clearly reported that laser light can effectively activate the production of plant primary and secondary metabolites [43]. The observed increase in the levels of organic acids in the laser-treated group of Cymbopogon proximus may be attributed to the decrease in the nitrate content. It is well documented that the nitrate content in plants is inversely correlated with the concentration of sugars and organic acids [44]. As laser treatment increases carbohydrate synthesis, this leads to an increase in the supply of ferredoxin and NADPH, which are used for the reduction of nitrate in leaves [45]. 
Table 3. Effect of He-Ne laser light treatment on sugar, amino acid, and organic acid contents in Cymbopogon proximus sprouts and seeds. Data are represented by means \pm standard error.

\begin{tabular}{|c|c|c|c|}
\hline Parameters & Seed-Control & Sprout-Control & Sprout-Laser \\
\hline \multicolumn{4}{|c|}{ Sugars } \\
\hline Glucose & $1.2 \pm 0.1 \mathrm{a}$ & $1.3 \pm 0 \mathrm{a}$ & $2.2 \pm 0.23 b$ \\
\hline Fructose & $0.32 \pm 0.04 \mathrm{a}$ & $0.49 \pm 0.05 b$ & $0.9 \pm 0.01 c$ \\
\hline Sucrose & $1.1 \pm 0.06 \mathrm{a}$ & $1.9 \pm 0.06 \mathrm{~b}$ & $2.7 \pm 0.09 \mathrm{~b}$ \\
\hline Soluble sugars & $4.9 \pm 0.7 \mathrm{a}$ & $5.4 \pm 0.2 \mathrm{a}$ & $10.3 \pm 2.6 \mathrm{a}$ \\
\hline Starch & $48.7 \pm 5.3 \mathrm{a}$ & $52.7 \pm 2.4 \mathrm{a}$ & $49.3 \pm 5.7 \mathrm{a}$ \\
\hline Total Carbohydrates & $83.7 \pm 3.8 \mathrm{a}$ & $92.7 \pm 2.1 \mathrm{~b}$ & $137 \pm 9.7 \mathrm{c}$ \\
\hline \multicolumn{4}{|c|}{ Amino Acids } \\
\hline Lysine & $2.1 \pm 0.1 \mathrm{a}$ & $3.9 \pm 0.2 b$ & $4.9 \pm 0.03 c$ \\
\hline Histidine & $2.1 \pm 0.12 \mathrm{a}$ & $2.8 \pm 0.22 \mathrm{a}$ & $2.7 \pm 0.17 \mathrm{a}$ \\
\hline Alanine & $16.9 \pm 2.1 \mathrm{a}$ & $17.3 \pm 1 \mathrm{a}$ & $18.9 \pm 1.7 \mathrm{a}$ \\
\hline Arginine & $1.1 \pm 0.61 \mathrm{a}$ & $2 \pm 0.01 \mathrm{~b}$ & $2.3 \pm 0.1 \mathrm{~b}$ \\
\hline Isoleucine & $0.02 \pm 0.0 \mathrm{a}$ & $0.2 \pm 0.01 \mathrm{~b}$ & $0.3 \pm 0.0 \mathrm{c}$ \\
\hline Asparagine & $0.4 \pm 0.06 \mathrm{a}$ & $1 \pm 0.06 \mathrm{~b}$ & $1.8 \pm 0.1 \mathrm{c}$ \\
\hline Ornithine & $0.15 \pm 0.01 \mathrm{a}$ & $0.2 \pm 0.03 a$ & $0.2 \pm 0.02 \mathrm{a}$ \\
\hline Glycine & $1.1 \pm 0.1 \mathrm{a}$ & $1.2 \pm 0.07 \mathrm{a}$ & $2 \pm 0.13 b$ \\
\hline Phenylalanine & $0.1 \pm 0.01 \mathrm{a}$ & $0.3 \pm 0.02 b$ & $0.7 \pm 0 \mathrm{c}$ \\
\hline Serine & $0.15 \pm 0.01 \mathrm{a}$ & $0.3 \pm 0.02 b$ & $0.6 \pm 0.04 b$ \\
\hline Proline & $1.1 \pm 0.1 \mathrm{a}$ & $1.1 \pm 0.07 \mathrm{a}$ & $2.4 \pm 0.1 \mathrm{c}$ \\
\hline Valine & $0.5 \pm 0.1 \mathrm{a}$ & $0.5 \pm 0.03 \mathrm{a}$ & $0.6 \pm 0.04 \mathrm{a}$ \\
\hline Aspartate & $0.01 \pm 0 \mathrm{a}$ & $0.03 \pm 0 \mathrm{~b}$ & $0.05 \pm 0 \mathrm{c}$ \\
\hline Cystine & $0.02 \pm 0 \mathrm{a}$ & $0.03 \pm 0 \mathrm{a}$ & $0.2 \pm 0.01 \mathrm{~b}$ \\
\hline Leucine & $0.03 \pm 0 \mathrm{a}$ & $0.02 \pm 0 \mathrm{a}$ & $0.03 \pm 0.1 \mathrm{a}$ \\
\hline Methionine & $0.01 \pm 0 \mathrm{a}$ & $0.02 \pm 0 \mathrm{~b}$ & $0.02 \pm 0 \mathrm{~b}$ \\
\hline Threonine & $0.1 \pm 0.0 \mathrm{a}$ & $0.1 \pm 0.01 \mathrm{a}$ & $0.2 \pm 0.01 \mathrm{~b}$ \\
\hline Tyrosine & $0.34 \pm 0.0 \mathrm{a}$ & $1 \pm 0.06 b$ & $1.3 \pm 0.1 b$ \\
\hline Glutamine & $71.1 \pm 1.8 \mathrm{a}$ & $91.7 \pm 5.6 \mathrm{~b}$ & $106 \pm 6.6 \mathrm{c}$ \\
\hline Glutamic acid & $54 \pm 3.1 \mathrm{a}$ & $67 \pm 4.2 \mathrm{~b}$ & $90 \pm 8.9 c$ \\
\hline \multicolumn{4}{|c|}{ Organic Acids } \\
\hline Oxalic & $2.11 \pm 0.2 \mathrm{a}$ & $2.84 \pm 0.2 \mathrm{a}$ & $3.04 \pm 0.1 \mathrm{a}$ \\
\hline Malic & $2.08 \pm 0.2 \mathrm{a}$ & $3.08 \pm 0.19 b$ & $4.72 \pm 1.5 \mathrm{c}$ \\
\hline Isobutyric & $3.1 \pm 0.1 \mathrm{a}$ & $3.2 \pm 0.2 \mathrm{a}$ & $4.1 \pm 1.37 \mathrm{a}$ \\
\hline Fumaric & $0.73 \pm 0.01 \mathrm{a}$ & $0.93 \pm 0.01 \mathrm{a}$ & $0.95 \pm 0.3 \mathrm{a}$ \\
\hline Succinic & $1.24 \pm 0.5 \mathrm{a}$ & $3.24 \pm 0.33 b$ & $4.15 \pm 1.1 \mathrm{c}$ \\
\hline Citric & $2.1 \pm 0.2 \mathrm{a}$ & $3.5 \pm 0.3 b$ & $5.4 \pm 1.8 \mathrm{c}$ \\
\hline
\end{tabular}

Different small letters $(\mathrm{a}, \mathrm{b}, \mathrm{c})$ within a row indicate significant differences between means at $p \leq 0.05$. Units: sugar (mg/g FW), amino acid (mg/100 g FW), organic acid (mg/g FW).

\subsection{Laser Treatment Increased the Levels of Essential Oils in Cymbopogon proximus Sprouts}

As laser light application increased the photosynthetic rate in Cymbopogon proximus sprouts, the biosynthesis of sugars, organic acids, and essential oils should be increased in a rhythmic manner. To verify this, an array of 18 essential oils was screened in the current 
study (Table 4). Essential oils are oily liquids produced through secondary metabolism in plants and can exert beneficial biological effects, which is the reason behind considering them as candidates for new drug screening [46]. As illustrated in Table 4, in the laser-treated sprouts of $C$. proximus, there were significant increases in the levels of $\alpha$-eudesmol (66\%), $\beta$-eudesmol (72\%), $\gamma$-eudesmol (68\%), elemol (52\%), terpinene $(66 \%)$, p-cymene $(65 \%)$, 1,8 -cineole $(65 \%)$, ocimene $(66 \%)$, piperitone $(40 \%)$, elemene $(65 \%)$, terpinene $(62 \%)$, and 3 -carene $(66 \%)$ in comparison to control sprouts. Additionally, control sprouts showed significantly $(p<0.05)$ richer values of 10 out of 18 essential oils than seeds (Table 4$)$. On the other hand, the laser-treated sprouts showed slight increases in the levels of linalool $(65 \%)$, linalyl acetate $(64 \%)$, and bourbobene $(63 \%)$ in comparison to the control group. In a recent study, the essential oils elemol, piperitone, $\alpha$-eudesmol, and $\beta$-eudesmol, separated from Cymbopogon proximus sprouts, were able together to protect rats against isoproterenolinduced cardiac hypertrophy and fibrosis [19]. In agreement with this, piperitone, elemol, $\alpha$ eudesmol, limonene, and $\beta$ - eudesmol are reported to be the main components of Cymbopogon proximus [15]. Interestingly, the essential oil of Cymbopogon proximus sprouts has been previously investigated for its cardio-protective effects [19]. Additionally, essential oils from Cymbopogon Flexuosus Steud. were utilized in the control of some vector-borne diseases [47].

Table 4. Effect of He-Ne laser light treatment on essential oil contents of Cymbopogon proximus sprouts and seeds. Data are represented by means \pm standard errors.

\begin{tabular}{cccc}
\hline $\begin{array}{c}\text { Essential Oils } \\
(\mathbf{m g} / \text { gFW })\end{array}$ & Seed-Control & Sprout-Control & Sprout-Laser \\
\hline$\alpha$-Pinene & $0.5 \pm 0.2 \mathrm{a}$ & $0.8 \pm 0.17 \mathrm{~b}$ & $1.3 \pm 0.3 \mathrm{~b}$ \\
\hline$\alpha$-Eudesmol & $0.2 \pm 0.0 \mathrm{a}$ & $0.3 \pm 0.05 \mathrm{~b}$ & $0.5 \pm 0.01 \mathrm{c}$ \\
\hline Elemol & $7.4 \pm 0.2 \mathrm{a}$ & $9.4 \pm 0.71 \mathrm{~b}$ & $14.2 \pm 0.4 \mathrm{c}$ \\
\hline$\alpha$-Terpinene & $1 \pm 0.1 \mathrm{a}$ & $1 \pm 0.15 \mathrm{a}$ & $1.6 \pm 0.2 \mathrm{a}$ \\
\hline p-Cymene & $3.4 \pm 0.6 \mathrm{a}$ & $5.6 \pm 0.64 \mathrm{~b}$ & $9.2 \pm 0.1 \mathrm{c}$ \\
\hline 1,8 -Cineole & $2.5 \pm 0.09 \mathrm{a}$ & $2.2 \pm 0.1 \mathrm{a}$ & $3.7 \pm 0.3 \mathrm{~b}$ \\
\hline Piperitone & $37.6 \pm 2.1 \mathrm{a}$ & $45.6 \pm 1.4 \mathrm{~b}$ & $64 \pm 2.9 \mathrm{c}$ \\
\hline$(\mathrm{E})$ - $\beta$-Ocimene & $0.7 \pm 0.03 \mathrm{a}$ & $1.28 \pm 0.2 \mathrm{~b}$ & $1.9 \pm 0.3 \mathrm{c}$ \\
\hline$\gamma$-Terpinene & $0.3 \pm 0.04 \mathrm{a}$ & $0.3 \pm 0.04 \mathrm{a}$ & $0.47 \pm 0.07 \mathrm{~b}$ \\
\hline$\alpha$-Terpinolene & $0.01 \pm 0 \mathrm{a}$ & $0.01 \pm 0 \mathrm{a}$ & $0.01 \pm 0 \mathrm{a}$ \\
\hline Linalool & $1.1 \pm 0.2 \mathrm{a}$ & $1 \pm 0.15 \mathrm{a}$ & $1.6 \pm 0.25 \mathrm{a}$ \\
\hline Linalyl acetate & $0.07 \pm 0.0 \mathrm{a}$ & $0.14 \pm 0.03 \mathrm{~b}$ & $0.23 \pm 0.05 \mathrm{c}$ \\
\hline$\beta$-Bourbobene & $0.24 \pm 0.01 \mathrm{a}$ & $0.3 \pm 0.02 \mathrm{a}$ & $0.49 \pm 0.04 \mathrm{~b}$ \\
\hline$\beta$-Elemene & $0.32 \pm 0.0 \mathrm{a}$ & $0.62 \pm 0.06 \mathrm{~b}$ & $1.0 \pm 0.1 \mathrm{~b}$ \\
\hline$\gamma$-Eudesmol & $0.10 \pm 0.0 \mathrm{a}$ & $0.18 \pm 0.03 \mathrm{a}$ & $0.31 \pm 0.04 \mathrm{~b}$ \\
\hline$\beta$-Eudesmol & $0.11 \pm 0.0 \mathrm{a}$ & $0.28 \pm 0.05 \mathrm{~b}$ & $0.47 \pm 0.08 \mathrm{c}$ \\
\hline$(Z)$ - $\beta$-Ocimene & $0.22 \pm 0.01 \mathrm{a}$ & $0.64 \pm 0.06 \mathrm{~b}$ & $1.06 \pm 0.11 \mathrm{c}$ \\
\hline$\delta$-3-Carene & $0.4 \pm 0.02 \mathrm{a}$ & $0.5 \pm 0.01 \mathrm{a}$ & $0.83 \pm 0.01 \mathrm{~b}$ \\
\hline Different small letters $(\mathrm{a}, \mathrm{b}, \mathrm{c})$ within $\mathrm{a}$ row indicate significant differences between means at $p \leq 0.05$. \\
\hline
\end{tabular}

\subsection{Improved Levels of Antioxidant Metabolites in Laser-Treated Cymbopogon proximus Sprouts}

It is known that the nutritive value of plants is greatly dependent on their contents of secondary metabolites such as phenolic compounds [48]. Phenolic compounds, as well as flavonoids, are well-known as antioxidants [49] and hence their levels represent a direct reflection of the nutritive value of plants. Previous studies have reported potential phytotherapeutic effects of phenolic products from Cymbopogon citratus [50]. In addition, 
for plants, these compounds act as defense mechanisms against environmental stress and attack by other organisms [49]. Here, the concentrations of seven phenolic acids and seven flavonoids, as well as the total phenolic content (TPC) and total flavonoid content (TFC), were quantified in the sprouts of Cymbopogon proximus. Interestingly, control sprouts showed significantly $(p<0.05)$ higher levels of eight out 14 measured phenolics and flavonoids compared to seeds. Furthermore, they were significantly richer in total phenolic and flavonoid compounds than seeds (Table 5). In addition, the laser-treated group of Cymbopogon proximus sprouts showed significant $(p<0.05)$ elevations in the levels of gallic acid (43\%), caffeic acid $(77 \%)$, protocatechuic acid $(27 \%)$, luteolin $(33 \%)$, apigenin $(32 \%)$, and TPC $(26 \%)$ in comparison with control sprouts. Additionally, the laser-treated group of Cymbopogon proximus sprouts showed slight increases in the levels of p-coumaric acid $(4 \%)$, chicoric acid (16\%), rosmarinic acid $(23 \%)$, kaempferol $(16 \%)$, chlorogenic acid $(25 \%)$, and TFC $(31 \%)$ in comparison to control sprouts. However, there were equivalent levels of quercetin, naringenin, and rutin in both laser-treated and control groups of sprouts (Table 5). Several of these reported phenolic compounds have been previously detected in Cymbopogon citratus [51]. A positive influence of laser light treatment on the growth and metabolism in seedlings of white lupine and faba beans has been reported [52]. Our previous study revealed laser light application as a powerful tool for improving the antioxidant levels of buckwheat sprouts [21].

Table 5. Effect of He-Ne laser light treatment on phenolic and flavonoid contents of Cymbopogon proximus sprouts and seeds. Data are represented by means \pm standard errors.

\begin{tabular}{cccc}
\hline Phenolics and Flavonoids (mg/gFW) & Seed-Control & Sprout-Control & Sprout-Laser \\
\hline Gallic acid & $0.21 \pm 0.03 \mathrm{a}$ & $0.29 \pm 0.02 \mathrm{a}$ & $0.5 \pm 0.05 \mathrm{~b}$ \\
\hline Caffeic acid & $0.22 \pm 0.0 \mathrm{a}$ & $0.42 \pm 0.03 \mathrm{~b}$ & $0.74 \pm 0.1 \mathrm{c}$ \\
\hline p-Coumaric acid & $1.10 \pm 0.1 \mathrm{a}$ & $2.27 \pm 0.1 \mathrm{~b}$ & $2.3 \pm 0.16 \mathrm{~b}$ \\
\hline Chicoric acid & $1.1 \pm 0.04 \mathrm{a}$ & $1.1 \pm 0.04 \mathrm{a}$ & $1.2 \pm 0.04 \mathrm{a}$ \\
\hline Rosmarinic acid & $1.0 \pm 0.07 \mathrm{a}$ & $1.0 \pm 0.07 \mathrm{a}$ & $1.7 \pm 0.05 \mathrm{~b}$ \\
\hline Protocatechuic acid & $1.1 \pm 0.01 \mathrm{a}$ & $3.1 \pm 0.06 \mathrm{~b}$ & $4.9 \pm 0.3 \mathrm{~b}$ \\
\hline Quercetin & $0.053 \pm 0.01 \mathrm{a}$ & $0.055 \pm 0.0 \mathrm{a}$ & $0.057 \pm 0.0 \mathrm{a}$ \\
\hline Isoquercetrin & $0.026 \pm 0.0 \mathrm{a}$ & $0.045 \pm 0.0 \mathrm{~b}$ & $0.046 \pm 0.0 \mathrm{~b}$ \\
\hline Kaempferol & $0.042 \pm 0.0 \mathrm{a}$ & $0.06 \pm 0.0 \mathrm{~b}$ & $0.07 \pm 0.0 \mathrm{~b}$ \\
\hline Luteolin & $0.06 \pm 0.01 \mathrm{a}$ & $0.06 \pm 0.0 \mathrm{a}$ & $0.08 \pm 0.0 \mathrm{~b}$ \\
\hline Apigenin & $0.03 \pm 0.02 \mathrm{a}$ & $0.06 \pm 0.02 \mathrm{~b}$ & $0.09 \pm 0.0 \mathrm{c}$ \\
\hline Naringenin & $0.004 \pm 0.0 \mathrm{a}$ & $0.01 \pm 0.0 \mathrm{~b}$ & $0.023 \pm 0.01 \mathrm{~b}$ \\
\hline Rutin & $0.001 \pm 0.0 \mathrm{a}$ & $0.007 \pm 0.0 \mathrm{~b}$ & $0.021 \pm 0.0 \mathrm{c}$ \\
\hline Chlorogenic acid & $0.0 \pm 0.0 \mathrm{a}$ & $0.0 \pm 0.0 \mathrm{a}$ & $0.017 \pm 0.0 \mathrm{~b}$ \\
\hline Total phenols & $6.43 \pm 0.4 \mathrm{a}$ & $9.43 \pm 0.1 \mathrm{~b}$ & $11.87 \pm 0.3 \mathrm{c}$ \\
\hline Total Flavonoids & $1.45 \pm 0.0 \mathrm{a}$ & $2.05 \pm 0.07 \mathrm{~b}$ & $2.91 \pm 0.1 \mathrm{c}$ \\
\hline
\end{tabular}

Different small letters $(\mathrm{a}, \mathrm{b}, \mathrm{c})$ within a row indicate significant differences between means at $p \leq 0.05$.

\subsection{Phenolic Compound Accumulation by Laser Treatment Improved the Overall Antioxidant Capacity of Cymbopogon proximus Sprouts}

As a consequence of increasing the antioxidant metabolites in Cymbopogon proximus sprouts, higher antioxidant activities were observed, as indicated by different antioxidant assays (FRAP, ORAC, DPPH) (Figure 1). Antioxidant activity is considered a key indicator of the nutritive value in edible plant parts [53]. In this regard, the antioxidant capacities of essential oils of Cymbopogon proximus have been previously reported [15]. There was also a shred of direct evidence for the link between the total phenolic and flavonoid content and the total antioxidant activities in many plant species [54]. As laser treatment 
resulted in increasing the levels of flavonoids, as well as phenolic compounds, in sprouts of Cymbopogon proximus, as clearly observed in Table 5, the laser-treated group of Cymbopogon proximus sprouts expressed significantly elevated levels of FRAP (Figure 1A), ORAC (Figure 1B), and DPPH (Figure 1C) in comparison to control sprouts. Furthermore, the control sprouts presented significantly higher values of FRAP, ORAC, and DPPH than control seeds (Figure 1). Moreover, a highly significant antioxidant activity (DPPH, ABTS, scavenging of the superoxide anion, and lipid peroxidation) has also been previously exhibited by Cymbopogon citratus [55]. In line with our study, the application of laser light increased the total antioxidant capacities (DPPH, FRAP, and ABTS) in buckwheat sprouts [21]. The observed enhanced antioxidant capacity after laser light application augments the previously reported enhancing effects of laser light on the total phenolic content of some plants such as soybeans [27] and sunflowers [23].

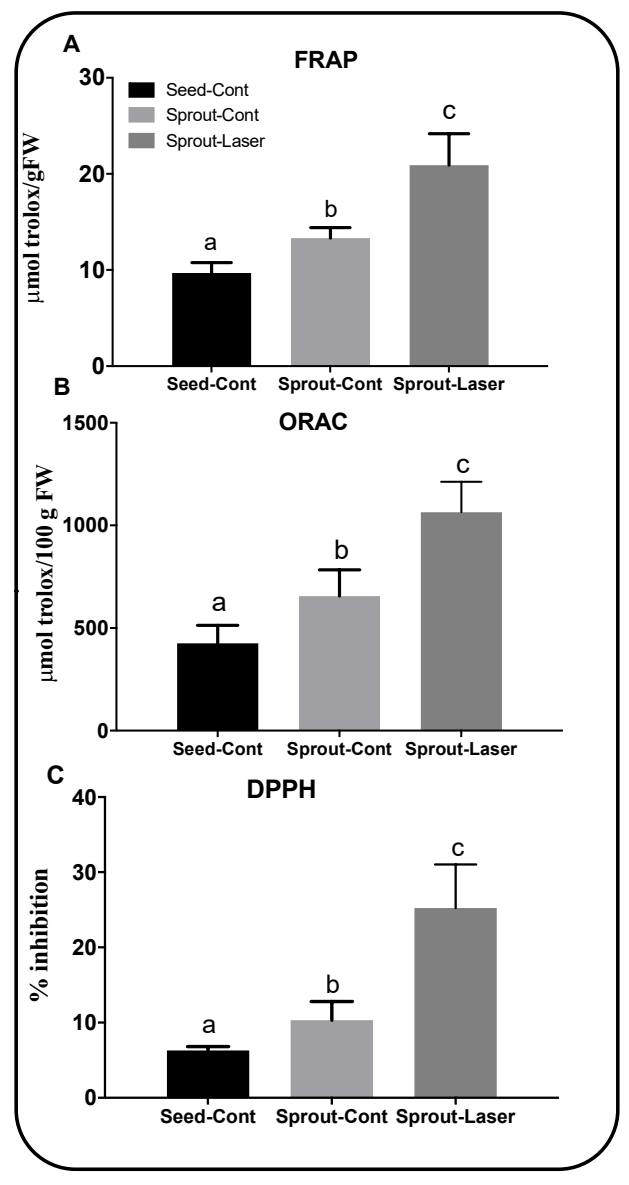

Figure 1. Effect of He-Ne laser light treatment on the total antioxidant capacity of Cymbopogon proximus sprouts and seeds. (A) FRAP (ferric reducing antioxidant power); (B) ORAC (oxygen radical absorbance); (C) DPPH (2,2-diphenyl-1-picryl-hydrazyl-hydrate). Data are represented by means \pm standard errors. Different small letters $(\mathrm{a}, \mathrm{b}, \mathrm{c})$ above bars indicate significant differences between means at $p<0.05$.

\subsection{Enhanced Cholesterol-Lowering Activity of Laser Light-Treated Cymbopogon proximus Sprouts}

As high cholesterol is the sixth risk factor for death in the world, cholesterol-lowering agents are considered to be of special relevance and many plant species have been investigated for their hypocholesterolemic potential [56]. The incorporation of dietary cholesterol into micelles is critical for absorption across the enterocytes into circulation. Consequently, the inhibition of cholesterol micellar solubility (CMS) is considered a parameter for anticholesterol activity measurement. As observed in Figure 2A, the percentage of CMS inhibition in the laser-treated group of Cymbopogon proximus sprouts is higher than that in the control group of sprouts. Additionally, the half maximal inhibitory concentration (IC50) 
of the tested sprouts against pancreatic amylase activity (Figure 2B) and pancreatic lipase activity (Figure 2C) were clearly reduced in the laser-treated group of Cymbopogon proximus sprouts in comparison to control sprouts. Moreover, these hypocholesterolemic activities were significantly $(p<0.05)$ greater in control sprouts than in control seeds (Figure 2$)$. Although the hypocholesterolemic effect of Cymbopogon spp. has been confirmed before [57], no studies, to the best of our knowledge, have reported this effect in Cymbopogon proximus or studied the enhancing effect of laser application on this effect. In this regard, Cymbopogon citratus extracts were able to reduce total cholesterol, triglycerides, and low-density lipoprotein (LDL) levels [58]. Thus, Cymbopogon citratus might contribute to maintaining a balance of cholesterol levels. This hypocholesterolemic activity is correlated with the availability of secondary metabolites such as phenolic compounds, which could play a role in getting rid of cholesterol in the feces [59]. Taken together, our current data illustrate the paramount importance of laser light application in the field of agricultural research, and further research is still needed to investigate the detailed mechanisms of these effects.

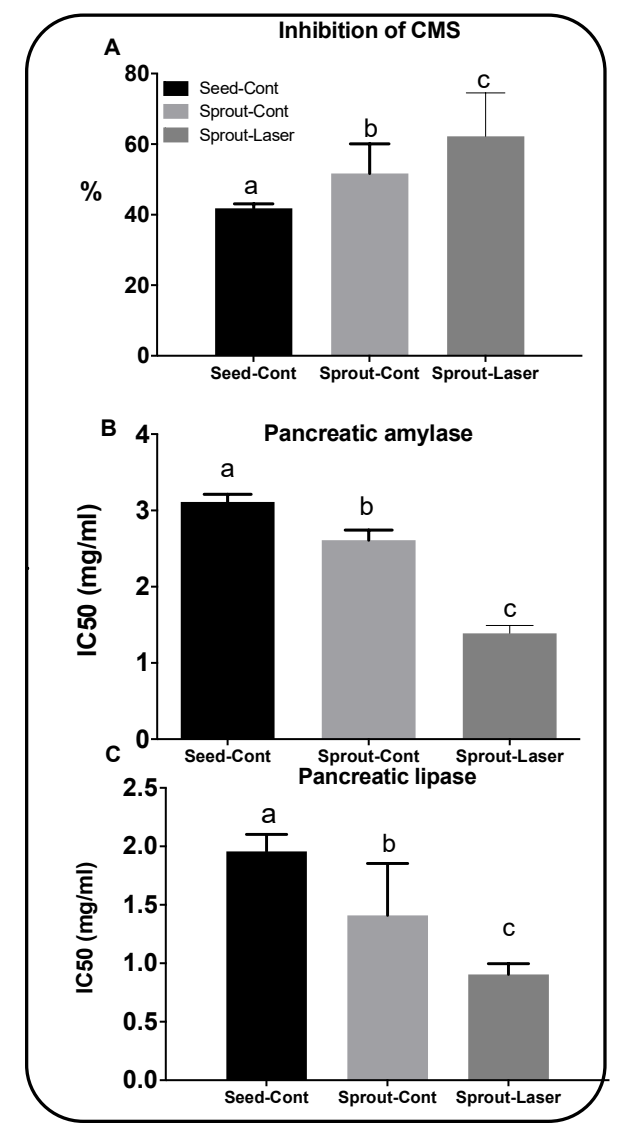

Figure 2. Effect of He-Ne laser light treatment on the anti-cholesterol activity of Cymbopogon proximus sprouts and seeds. (A) inhibition of CMS (cholesterol micellar solubility); (B) Pancreatic amylase; (C) Pancreatic lipase. Data are represented by means \pm standard errors. Different small letters $(a, b$, c) above bars indicate significant differences between means at $p \leq 0.05$.

\subsection{Improved Anti-Diabetic Activity of Laser-Treated Cymbopogon proximus Sprouts}

Furthermore, we assessed the effect of both sprouting and laser treatment separately and in combination on the anti-diabetic activity of laser-treated Cymbopogon proximus (Figure 3). Remarkably, control sprouts had a significantly lower glycemic index (Figure 3A) $(p<0.05)$ and higher anti-diabetic activities - namely, $\alpha$-glucosidase inhibition activity (Figure 3B) and $\alpha$-amylase inhibition activity (Figure 3C) - than control seeds. In addition, laser-treated sprouts had significantly higher glycemic index values and $\alpha$-glucosidase inhibition activity, as well as slightly higher $\alpha$-amylase inhibition activity (Figure 3). The glycemic index concept was 
developed as a tool to select healthy foods for diabetic patients. According to its effect on blood glucose levels after consumption, it is classified as low ( $\leq 55)$, medium (56-69), and high ( $\geq 70$ ) [58]. Glycemic index mainly relies on the absorption of carbohydrates, i.e., lowering the absorption of carbohydrates causes low blood glucose levels and therefore a low glycemic index. The composition and microstructure of food, such as the sugar profile and antioxidant secondary metabolites, are contributing factors in a food's glycemic index $[59,60]$. Thus, the observed low glycemic index of sprouts, particularly after laser light treatment, could be due to the accumulation of soluble sugars (sucrose, fructose), essential oils and amino acids, and antioxidant polyphenols [59,60]. Increased inhibition percentages of $\alpha$-amylase and $\alpha$ glucosidase by sprouting and seed treatment with laser light can be correlated with high levels of tocopherol and phenolics [61,62]. For instance, the high availability of quercetin, $\rho$-coumaric, and gallic acid possibly exert the effect on $\alpha$-amylase and $\alpha$-glucosidase inhibition [61]. Appositive correlation with total antioxidant capacity (DPPH) was observed [59].

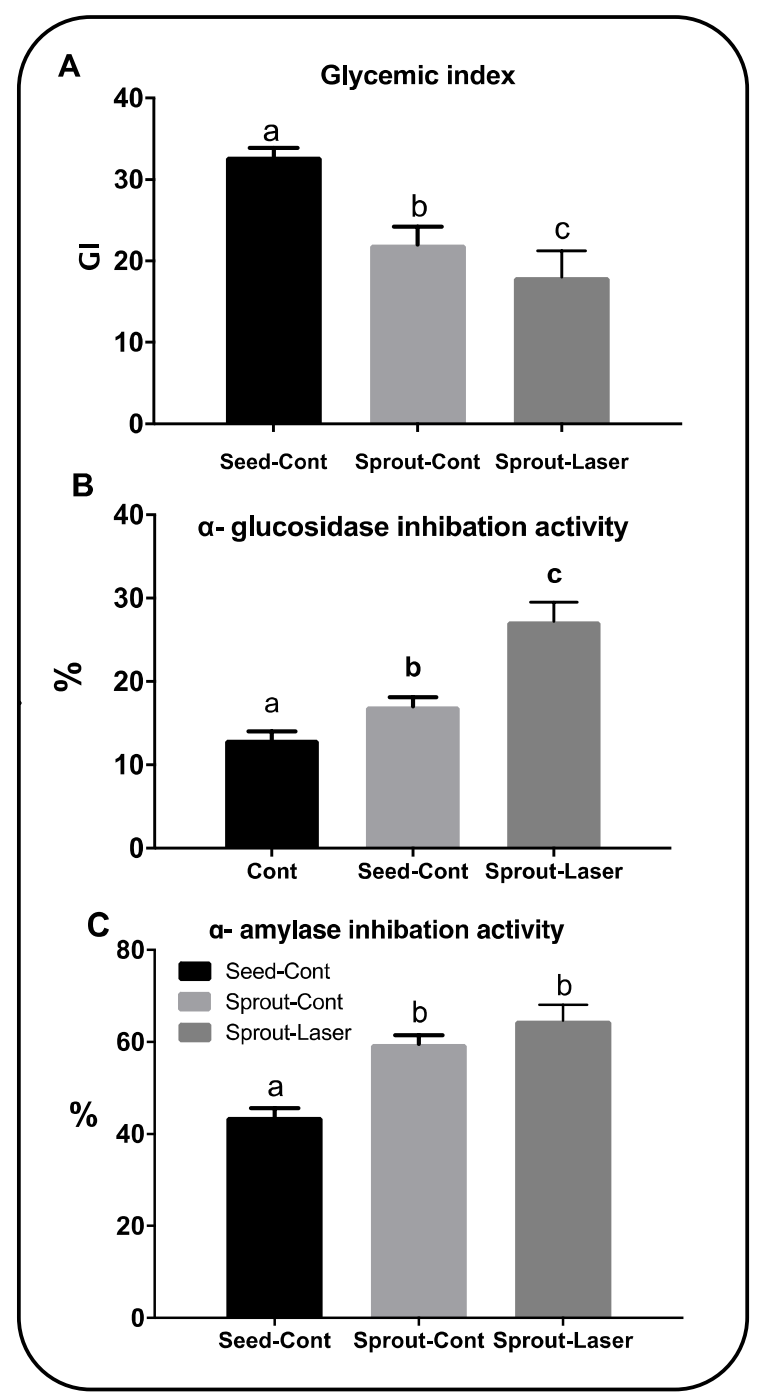

Figure 3. Effect of He-Ne laser light treatment on the anti-diabetic activity of Cymbopogon proximus sprouts and seeds. (A) glycemic index; (B) $\alpha$-glucosidase inhibition activity; (C) $\alpha$-amylase inhibition actrivity. Data are represented by means \pm standard errors. Different small letters $(a, b, c)$ above bars indicate significant differences between means at $p<0.05$.

\subsection{Cluster Analysis}

The hierarchical clustering data of 66 measured parameters, shown in Figure 4, confirm the synergistic effect of laser light treatment with sprouting on most of the measured 
parameters. Given that the lowest values of most measured metabolites and biological activities were found in untreated seeds, whereas sprouts cultivated from untreated seeds showed moderate values, sprouts grown from laser-treated seeds had the highest values of most metabolites and the highest biological activity results. Only for chlorogenic acid were the lowest values detected in laser light-treated sprouts. Furthermore, no effect of laser treatment nor sprouting was detectable in the case of alpha-terpinolene. Higher values of leucine were also found in seeds and treated sprouts than in control sprouts. The rest of the parameters can be divided into three large clusters, highlighting the synergism of sprouting with laser treatment.

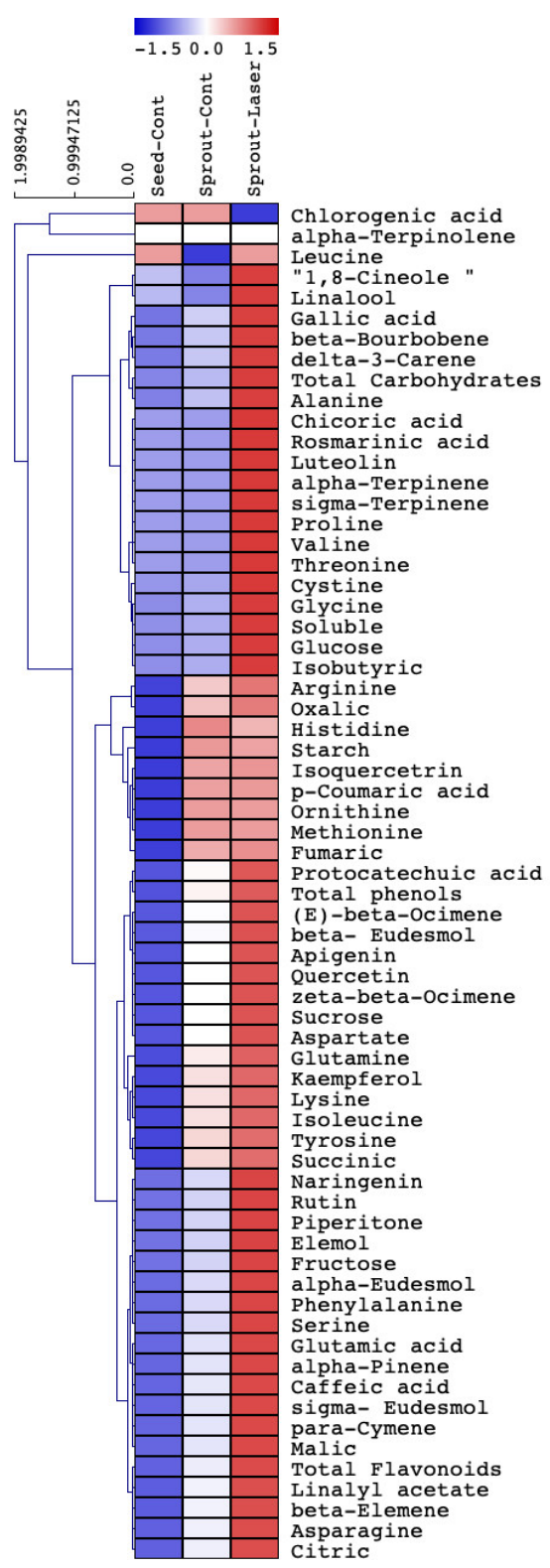

Figure 4. Heatmap showing the effect of He-Ne laser light treatment on growth, photosynthesis, respiration, metabolites, and biological activity of Cymbopogon proximus sprouts and seeds.

\section{Conclusions}

Laser light improved the photosynthetic activity, respiration, and hence the fresh weight of Cymbopogon proximus sprouts. Sprouting increased the bioactive primary and secondary metabolites as compared to seeds. Enhanced photosynthesis by laser light further improved the synthesis of amino acids, organic acids, and essential oils, as well as 
phenolics and flavonoids. Accordingly, laser treatment significantly improved antioxidant, hypocholesterolemic, and antidiabetic activities. Similar to most physical factors, laser light modifies only the physiological and biochemical processes in seeds, so it is safe for humans and the environment [63]. Moreover, in contrast to high doses of laser light, which induce plant mutation, the applied low dose of laser light in the current study only induced biostimulation effects. Overall, the synergism of laser light treatment and sprouting of plants could be deemed as a promising tool for improving the nutraceutical and biological values of edible plants. This is especially true for plants that have been documented to possess highly enriched contents of bioactive compounds and biologically relevant metabolites that can be used in promising functional food and therapeutic applications.

Author Contributions: Conceptualization, M.K.O. and H.A.; methodology, M.K.O., H.A. and M.A.E.-T.; software, A.H.A.H.; validation, M.A.B., Y.B.E. and A.H.A.H.; formal analysis, M.A.B., A.A.Q. and M.A.E.-T.; investigation, M.K.A.; resources, H.A. and A.H.A.H.; data curation, H.A., A.H.A.H. and M.K.O.; writing-original draft preparation, M.A.A.-M., H.A. and A.H.A.H.; writingreview and editing, M.K.O., M.A.B., A.H.A.H. and H.A.; visualization, H.A.; supervision, H.A.; project administration, Y.B.E.; funding acquisition, M.K.O. All authors have read and agreed to the published version of the manuscript.

Funding: This research was funded by the Deanship of Scientific Research at King Saud University through research group No (RG-1441-485).

Institutional Review Board Statement: Not applicable.

Informed Consent Statement: Not applicable.

Data Availability Statement: Not applicable.

Acknowledgments: The authors extend their appreciation to the Deanship of Scientific Research at King Saud University for funding this work through research group No (RG-1441-485).

Conflicts of Interest: The authors declare no conflict of interest.

\section{References}

1. Swieca, M.; Gawlik-Dziki, U.; Jakubczyk, A.; Bochnak, J.; Sikora, M.; Suliburska, J. Nutritional quality of fresh and stored legumes sprouts-Effect of Lactobacillus plantarum 299v enrichment. Food Chem. 2019, 288, 325-332. [CrossRef] [PubMed]

2. Márton, M.; Mándoki, Z.S.; Csapo-Kiss, Z.S.; Csapó, J. The role of sprouts in human nutrition. A review. Acta Univ. Sapientiae Aliment. 2010, 3, 81-117.

3. AbdulAzeez, M.A.; Abdullahi, A.S.; James, B.D. Lemongrass (Cymbopogon spp.) Oils. In Essential Oils in Food Preservation, Flavor and Safety; Elsevier: Amsterdam, The Netherlands, 2016; pp. 509-516.

4. Avoseh, O.; Oyedeji, O.; Rungqu, P.; Nkeh-Chungag, B.; Oyedeji, A. Cymbopogon species; ethnopharmacology, phyto-chemistry and the pharmacological importance. Molecules 2015, 20, 7438-7453. [CrossRef]

5. Dutta, S.; Munda, S.; Lal, M.; Bhattacharyya, P.R. A short review on chemical composition therapeutic use and enzyme inhi-bition activities of Cymbopogon species. Indian J. Sci. Technol. 2016, 9, 1-9. [CrossRef]

6. Ganjewala, D. Cymbopogon essential oils: Chemical compositions and bioactivities. Int. J. Essent. Oil Ther. 2009, 3, 56-65.

7. Miguel, M.G. Antioxidant and Anti-Inflammatory Activities of Essential Oils: A Short Review. Molecules 2010, 15, 9252-9287. [CrossRef] [PubMed]

8. $\quad$ Ekpenyong, C.E.; Davies, K.; Antai, E.E. Cymbopogon citratus Stapf (DC) Extract Ameliorates Atherogenic Cardiovascular Risk in Diabetes-Induced Dyslipidemia in Rats. Br. J. Med. Med. Res. 2014, 4, 4695-4709. [CrossRef]

9. Mansour, H.A.; Newairy, A.-S.; Yousef, M.; Sheweita, S. Biochemical study on the effects of some Egyptian herbs in alloxaninduced diabetic rats. Toxicology 2002, 170, 221-228. [CrossRef]

10. Adeneye, A.A.; Agbaje, E.O. Hypoglycemic and hypolipidemic effects of fresh leaf aqueous extract of Cymbopogon citratus Stapf. in rats. J. Ethnopharmacol. 2007, 112, 440-444. [CrossRef]

11. Campos, J.; Schmeda-Hirschmann, G.; Leiva, E.; Guzmán, L.; Orrego, R.; Fernández, P.; González, M.; Radojkovic, C.; Zuñi-ga, F.A.; Lamperti, L.; et al. Lemon grass (Cymbopogon citratus (D.C) Stapf) polyphenols protect human umbilical vein endo-thelial cell (HUVECs) from oxidative damage induced by high glucose, hydrogen peroxide and oxidised low-density lipo-protein. Food Chem. 2014, 151, 175-181. [CrossRef]

12. Khan, S.J.; Afroz, S.; Khan, R.A. Anti-hyper lipidemic and anti-hyperglycemic effects of Cymbopogon jwarancusa in high-fat high-sugar Diet model. Pak. J. Pharm. Sci. 2018, 31, 1341-1345.

13. El-Askary, H.I.; Meselhy, M.R.; Galal, A.M. Sesquiterpenes from Cymbopogon proximus. Molecules 2003, 8, 670-677. [CrossRef] 
14. Ibrahim, F.Y.; El-Khateeb, A. Effect of herbal beverages of Foeniculum vulgare and Cymbopogon proximus on inhibition of calcium oxalate renal crystals formation in rats. Ann. Agric. Sci. 2013, 58, 221-229. [CrossRef]

15. Selim, S.A. Chemical composition, antioxidant and antimicrobial activity of the essential oil and methanol extract of the Egyptian lemongrass Cymbopogon proximus Stapf. Grasas Aceites 2011, 62, 55-61. [CrossRef]

16. Warrag, N.M.; Tag Eldin, I.M.; Ahmed, E.M. Effect of Cymbopogon proximus (Mahareb) on ethylene glycol-induced nephro-lithiasis in rats. Afr. J. Pharm. Pharm. 2014, 8, 443-450.

17. El-Nezhawy, A.O.H.; Maghrabi, I.A.; Mohamed, K.M.; Omar, H.A. Cymbopogon proximus extract decreases L-NAME-induced hypertension in rats. Int. J. Pharm. Sci. Rev. Res. 2014, 27, 66-69.

18. El Tahir, K.; Abdel-Kader, M. Chemical and pharmacological study of Cymbopogon proximus volatile oil. Res. J. Med. Plant 2008, 2, 53-60.

19. Althurwi, H.N.; Abdel-Kader, M.S.; Alharthy, K.M.; Salkini, M.A.; Albaqami, F.F. Cymbopogon Proximus Essential Oil Protects Rats against Isoproterenol-Induced Cardiac Hypertrophy and Fibrosis. Molecules 2020, 25, 1786. [CrossRef]

20. Almuhayawi, M.; AbdElgawad, H.; Al Jaouni, S.; Selim, S.; Hassan, A.H.A.; Khamis, G. Elevated $\mathrm{CO}_{2}$ improves glucos-inolate metabolism and stimulates anticancer and anti-inflammatory properties of broccoli sprouts. Food Chem. 2020, $328,127102$. [CrossRef] [PubMed]

21. Almuhayawi, M.; Hassan, A.H.A.; Abdel-Mawgoud, M.; Khamis, G.; Selim, S.; Al Jaouni, S.; AbdElgawad, H. Laser light as a promising approach to improve the nutritional value, antioxidant capacity and anti-inflammatory activity of flavo-noid-rich buckwheat sprouts. Food Chem. 2021, 345, 128788. [CrossRef] [PubMed]

22. Almuhayawi, M.S.; Hassan, A.H.; Al Jaouni, S.K.; Alkhalifah, D.H.M.; Hozzein, W.N.; Selim, S.; Khamis, G. Influence of elevated $\mathrm{CO} 2$ on nutritive value and health-promoting prospective of three genotypes of Alfalfa sprouts (Medicago Sativa). Food Chem. 2021, 340, 128147. [CrossRef]

23. Perveen, R.; Jamil, Y.; Ashraf, M.; Ali, Q.; Iqbal, M.; Ahmad, M.R. He-Ne Laser-Induced Improvement in Biochemical, Physiological, Growth and Yield Characteristics in Sunflower (Helianthus annuus L.). Photochem. Photobiol. 2011, 87, 1453-1463. [CrossRef]

24. Chen, Y.P.; Yue, M. and Wang, X.L. Influence of He-Ne Laser Irradiation on Seeds Thermodynamic Parameters and Seed-lings Growth of Isatis indogotica. Plant Sci. 2005, 168, 601-606. [CrossRef]

25. Ooi, A.; Wong, A.; Ng, T.K.; Marondedze, C.; Gehring, C.; Ooi, B.S. Growth and development of Arabidopsis thaliana under single-wavelength red and blue laser light. Sci. Rep. 2016, 6, 33885. [CrossRef] [PubMed]

26. Murase, H. The Latest Development of Laser Application Research in Plant Factory. Agric. Agric. Sci. Procedia 2015, 3, 4-8. [CrossRef]

27. Asghar, T.; Jamil, Y.; Iqbal, M.; Haq, Z.U.; Abbas, M. Laser light and magnetic field stimulation effect on biochemical, enzymes activities and chlorophyll contents in soybean seeds and seedlings during early growth stages. J. Photochem. Photobiol. B Biol. 2016, 165, 283-290. [CrossRef]

28. AbdelGawad, H.; Peshev, D.; Zinta, G.; Ende, W.V.D.; Janssens, I.A.; Asard, H. Climate Extreme Effects on the Chemical Composition of Temperate Grassland Species under Ambient and Elevated $\mathrm{CO}_{2}$ : A Comparison of Fructan and Non-Fructan Accumulators. PLoS ONE 2014, 9, e92044. [CrossRef]

29. Zinta, G.; AbdElgawad, H.; Peshev, D.; Weedon, J.T.; Van den Ende, W.; Nijs, I.; Janssens, I.A.; Beemster, G.T.; Asard, H. Dynamics of metabolic responses to periods of combined heat and drought in Arabidopsis thaliana under ambient and ele-vated atmospheric $\mathrm{CO}_{2}$. J. Exp. Bot. 2018, 69, 2159-2170. [CrossRef]

30. Hassanpour, H.; Khavari-Nejad, R.A.; Niknam, V.; Razavi, K.; Najafi, F. Effect of pen-conazole and drought stress on the essential oil composition and gene expression of Menthapulegium L.(Lamiaceae) at flowering stage. Acta Physiol. Plant. 2014, 36, 1167-1175. [CrossRef]

31. Hamad, I.; AbdelGawad, H.; Al Jaouni, S.; Zinta, G.; Asard, H.; Hassan, S.T.S.; Hegab, M.; Hagagy, N.; Selim, S.A. Metabolic Analysis of Various Date Palm Fruit (Phoenix dactylifera L.) Cultivars from Saudi Arabia to Assess Their Nutritional Quality. Molecules 2015, 20, 13620-13641. [CrossRef] [PubMed]

32. Al Jaouni, S.; Saleh, A.M.; Wadaan, M.A.; Hozzein, W.N.; Selim, S.; AbdElgawad, H. Elevated $\mathrm{CO}_{2}$ induces a global metabolic change in basil (Ocimum basilicum L.) and peppermint (Mentha piperita L.) and improves their biological activity. J. Plant Physiol. 2018, 121-131. [CrossRef]

33. Hozzein, W.N.; Saleh, A.M.; Habeeb, T.H.; Wadaan, M.A.; AbdelGawad, H. $\mathrm{CO}_{2}$ treatment improves the hypocholesterolemic and antioxidant properties of fenugreek seeds. Food Chem. 2020, 308, 125661. [CrossRef]

34. Hasan, M.; Hanafiah, M.M.; Taha, Z.A.; Alhilfy, I.H.H.; Said, M.N.M. Laser Irradiation Effects at Different Wavelengths on Phenology and Yield Components of Pretreated Maize Seed. Appl. Sci. 2020, 10, 1189. [CrossRef]

35. Qiu, Z.; Yuan, M.; He, Y.; Li, Y.; Zhang, L. Physiological and transcriptome analysis of He-Ne laser pre-treated wheat seedlings in response to drought stress. Sci. Rep. 2017, 7, 6108. [CrossRef] [PubMed]

36. O'Hara, L.E.; Paul, M.J.; Wingler, A. How Do Sugars Regulate Plant Growth and Development? New Insight into the Role of Trehalose-6-Phosphate. Mol. Plant 2013, 6, 261-274. [CrossRef] [PubMed]

37. Lastdrager, J.; Hanson, J.; Smeekens, S. Sugar signals and the control of plant growth and development. J. Exp. Bot. 2014, 65, 799-807. [CrossRef] [PubMed] 
38. Al Jaouni, S.K.; Al Muhayawi, M.S.; Hussein, A.; Elfiki, I.; Al-Raddadi, R.; Al Muhayawi, S.M.; Harakeh, S. Effects of Honey on Oral Mucositis among Pediatric Cancer Patients Undergoing Chemo/Radiotherapy Treatment at King Abdulaziz University Hospital in Jeddah, Kingdom of Saudi Arabia. Evid. Based Complement. Altern. Med. 2017, 2017, 5861024. [CrossRef] [PubMed]

39. Ufaz, S.; Galili, G. Improving the Content of Essential Amino Acids in Crop Plants: Goals and Opportunities. Plant Physiol. 2008, 147, 954-961. [CrossRef]

40. Khan, S.; Yu, H.; Li, Q.; Gao, Y.; Sallam, B.N.; Wang, H.; Jiang, W. Exogenous Ap-plication of Amino Acids Improves the Growth and Yield of Lettuce by Enhancing Photosynthetic Assimilation and Nutrient Availability. Agronomy 2019, 9, 266. [CrossRef]

41. Teixeira, W.F.; Fagan, E.B.; Soares, L.H.; Soares, J.N.; Reichardt, K.; Neto, D.D. Seed and Foliar Application of Amino Acids Improve Variables of Nitrogen Metabolism and Productivity in Soybean Crop. Front. Plant Sci. 2018, 9, 396. [CrossRef] [PubMed]

42. Malundo, T.; Shewfelt, R.; Ware, G.; Baldwin, E. Sugars and Acids Influence Flavor Properties of Mango (Mangifera indica). J. Am. Soc. Hortic. Sci. 2001, 126, 115-121. [CrossRef]

43. Li, X.; Zhang, L.; Ahammed, G.J.; Li, Z.-X.; Wei, J.-P.; Shen, C.; Wen-Yan, H.; Zhang, L.-P.; Han, W.-Y. Stimulation in primary and secondary metabolism by elevated carbon dioxide alters green tea quality in Camellia sinensis L. Sci. Rep. 2017, 7, 7937. [CrossRef] [PubMed]

44. Champigny, M.L. Integration of photosynthetic carbon and nitrogen metabolism in higher plants. Photosynth. Res. 1995, 46, 117-127. [CrossRef] [PubMed]

45. Velez-Ramirez, A.I.; Van Ieperen, W.; Vreugdenhil, D.; Millenaar, F.F. Plants under continuous light. Trends Plant Sci. 2011, 16, 310-318. [CrossRef]

46. Seibert, J.B.; Rodrigues, I.V.; Carneiro, S.P.; Amparo, T.R.; Lanza, J.S.; Frézard, F.J.G.; Santos, O.D.H.D. Frézard Gustavo Henrique Bianco de Souza Orlando David Henrique dos Santos. Seasonality study of essential oil from leaves of Cymbopogon densiflorus and nanoemulsion development with antioxidant activity. Flavour Fragr. J. 2019, 34, 5-14. [CrossRef]

47. Bhatta, L.; Kale, R.D. Research articleLemongrass (Cymbopogon Flexuosus Steud.) wats treated textile: A control measure against vector-borne diseases. Heliyon 2019, 5, e02842. [CrossRef] [PubMed]

48. De Beer, D.; Joubert, E.; Gelderblom, W.; Manley, M. Phenolic Compounds: A Review of Their Possible Role as In Vivo Antioxidants of Wine. S. Afr. J. Enol. Vitic. 2017, 23, 48-61. [CrossRef]

49. Tungmunnithum, D.; Thongboonyou, A.; Pholboon, A.; Yangsabai, A. Flavonoids and Other Phe-nolic Compounds from Medicinal Plants for Pharmaceutical and Medical Aspects: An Overview. Medicines 2018, 5, 93. [CrossRef]

50. Costa, G.; Ferreira, J.P.; Vitorino, C.; Pina, M.E.; Sousa, J.J.; Figueiredo, I.V.; Batista, M.T. Polyphenols from Cymbopogon citratus leaves as topical anti-inflammatory agents. J. Ethnopharmacol. 2016, 178, 222-228. [CrossRef]

51. Figueirinha, A.; Cruz, M.T.; Francisco, V.L.G.; Lopes, M.C.; Batista, M.T. Anti-Inflammatory Activity of Cymbopogon citratus Leaf Infusion in Lipopolysaccharide-Stimulated Dendritic Cells: Contribution of the Polyphenols. J. Med. Food 2010, 13, 681-690. [CrossRef]

52. Podleśny, J.; Stochmal, A.; Podleśna, A.; Misiak, L.E. Effect of laser light treatment on some bio-chemical and physiological processes in seeds and seedlings of white lupine and faba bean. Plant Growth Regul. 2012, 67, 227-233. [CrossRef]

53. León-López, L.; Escobar-Zúñiga, Y.; Salazar-Salas, N.Y.; Rochín, S.M.; Cuevas-Rodríguez, E.O.; Reyes-Moreno, C.; Milán-Carrillo, J. Improving Polyphenolic Compounds: Antioxidant Activity in Chickpea Sprouts through Elicitation with Hydrogen Peroxide. Foods 2020, 9, 1791. [CrossRef] [PubMed]

54. Zhou, C.; Sun, C.; Chen, K.; Li, X. Flavonoids, Phenolics, and Antioxidant Capacity in the Flower of Eriobotrya japonica Lindl. Int. J. Mol. Sci. 2011, 12, 2935-2945. [CrossRef]

55. Mohammad, T.; Khudhur, D. Evaluation of the bio-stainging and antioxidant activity of Cymbopogon citratus extraction grass. Asian J. Microbiol. Biotech. Environ. Sci. 2018, 20, 848-856.

56. Gururaja, G.M.; Mundkinajeddu, D.; Kumar, A.S.; Dethe, S.M.; Allan, J.J.; Agarwal, A. Cite Evaluation of Cholesterol-lowering Activity of Standardized Extract of Mangifera indica in Albino Wistar Rats. Pharmacogn. Res. 2017, 9, 21-26.

57. Agbafor, K.N.; Akubugwo, E.I. Hypocholesterolaemic effect of ethanolic extract of fresh leaves of Cymbopogon citratus (lemon grass). Afr. J. Biotechnol. 2007, 6, 596-598.

58. Sosnowska, D.; Podsędek, A.; Redzynia, M.; Kucharska, A.Z. Inhibitory effect of black chokeberry fruit polyphenols on pancreatic lipase-Searching for most active inhibitors. J. Funct. Foods 2018, 49, 196-204. [CrossRef]

59. Oboh, G.; Ademosun, A.O.; Akinleye, M.; Omojokun, O.S.; Boligon, A.A.; Athayde, M.L. Starch composition, glycemic indices, phenolic constituents, and antioxidative and antidiabetic properties of some common tropical fruits. J. Ethn. Foods 2015, 2, 64-73. [CrossRef]

60. Kim, Y.-M.; Jeong, Y.-K.; Wang, M.-H.; Lee, W.-Y.; Rhee, H.-I. Inhibitory effect of pine extract on $\alpha$-glucosidase activity and postprandial hyperglycemia. Nutrition 2005, 21, 756-761. [CrossRef]

61. Loizzo, M.R.; Bonesi, M.; Menichini, F.; Tenuta, M.C.; Leporini, M.; Tundis, R. Antioxidant and Carbohydrate-Hydrolysing Enzymes Potential of Sechium edule (Jacq.) Swartz (Cucurbitaceae) Peel, Leaves and Pulp Fresh and Processed. Plant Foods Hum. Nutr. 2016, 71, 381-387. [CrossRef]

62. Wongsa, P.; Chaiwarit, J.; Zamaludien, A. In vitro screening of phenolic compounds, potential inhibition against $\alpha$-amylase and $\alpha$-glucosidase of culinary herbs in Thailand. Food Chem. 2012, 131, 964-971. [CrossRef]

63. Smalley, P.J. Laser safety: Risks, hazards, and control measures. Laser Ther. 2011, 20, 95-106. [CrossRef] [PubMed] 